\title{
Adaptive Governance for Building Urban Resilience: Lessons from Water Management Strategies in Two Indonesian Coastal Cities
}

\author{
Ewin Sofian Winata' \\ Ministry of National Development Planning/BAPPENAS - Indonesia \\ Samuel Geldin' ${ }^{2}$ Kristin Qui \\ Yale University - USA
}

\begin{abstract}
Using a combination of vulnerability and resilience frameworks, this paper examines governance challenges and strategies to coastal and water-related resilience in two Indonesian cities. It compares the methods that local governments have used to engage different stakeholders and enact various policy solutions, in order to understand how multi-scalar elements of governance influence vulnerability and adaptive capacity to water-related hazards. After discussing shocks and stresses of note that span the social, economic and environmental realm, a comparative analysis will be carried out for two large coastal cities in Indonesia, Surabaya and Semarang. A combination of resilience frameworks as a basis for analysis reveals the different approach of each city to enhance resilience. While Surabaya centered on enhancing people participation and efforts internally, Semarang more focused on instituting comprehensive plans and external collaboration. These different approaches suggest that resilience can be built from different ways. A combination of adequate financing, technical capacity, excellent leadership, an understanding of the root causes and pressures, and long-term visions is necessary for impactful governance.
\end{abstract}

Keywords: vulnerability, resilience, water-related hazard, coastal city, governance

S Staff at Directorate for Water Resources and Irrigation, Bappenas, Jl. Taman Suropati No. 2 Jakarta 10310. Tel. (021) 3926186 Email: ewin.sofianwinata@bappenas.go.id

${ }^{2}$ Yale University, School of Forestry and Environmental Studies, New Haven, CT, USA. Email: Samuel.geldin@yale.edu, Kristin. qui@yale.edu 


\title{
Adaptive Governance for Building Urban Resilience: Lessons from Water Management Strategies in Two Indonesian Coastal Cities
}

\author{
Ewin Sofian Winata, BAPPENAS
}

\section{Introduction: Stresses and Shocks in Indonesia Amid Climate Change}

Indonesia is considered to be the world's largest archipelagic state, with over 17,000 islands and a population of about 250 million (Wingqvist and Dahlberg, 2008). $65 \%$ of people live near the coast and $75 \%$ of cities are also located along the coast (Khomarudin, 2013). These characteristics, coupled with low elevation, make Indonesian coastal cities susceptible to a range of climate-related stresses, and ultimately to climate-related shocks. The island of Java, in particular, faces many challenges that include rapid high urbanization, poverty, and underemployment (Wingqvist and Dahlberg, 2008).

Urbanization in coastal cities has increasingly problematic consequences. Both cities of interest in this paper, Semarang and Surabaya, are subject to very high rates of urbanization and have high population densities - 7000 persons $/ \mathrm{km} 2$ in Surabaya and 7100 persons/km2 in Semarang (Asian Development Bank, 2016). Rapid urbanization has encouraged the development of informal settlements referred to as kampungs, which are unplanned low-income communities without legal land tenure (Ernawati et al., 2013). These informal coastal settlements are particularly vulnerable to environmental phenomena such as sea level rise, coastal inundation, land subsidence, coastal erosion, and tidal flooding (Marfai et al., 2007; Wijaya, 2015). Exposure to these climate-related stresses - defined by the IPCC (2014) as "the presence of people, livelihoods, species or ecosystems, environmental functions, services, and resources, infrastructure...in places and settings that could be adversely affected" - exacerbate other social and economic elements. Half of Indonesia's population lives below the poverty line of US\$2 per day and contribute to very high unemployment and underemployment rates (Wingqvist and Dahlberg, 2008). Lowincome households typically participate in the informal sector, which depends on small trade and home-based activities. If there were to be any disruption to these informal settlements, however, their sources of income could be eliminated. Since coastal cities may not have access to the necessary resources for all citizens in times of disaster, the economic security of people working in the informal sector constitute a high local priority.

The cities of Semarang and Surabaya also face water-related stresses. Semarang has a history of overexploitation of groundwater resources. Semarang has depended on its own groundwater to meet an increasing demand for water as a result of high population.. However, tapping local aquifers has led to a steep reduction in groundwater levels, which has in turn resulted in land subsidence and seawater intrusion (Marfai et al., 2007; City of Semarang, 2016). As a result of climate change, major annual and seasonal changes in precipitation are projected for the future and have already been observed. Scientists project a $10 \%$ increase in rainfall between April and June, and a $75 \%$ decrease in rainfall in the dry season between July and September, as a result of climate change. These changes will impact water availability in many ways, increasing the possibility of droughts in the dry season and flooding during the rainy season, which could ultimately displace a large number of people living in these coastal cities. Coastal flooding is another water-related stress and shock that occurs frequently in many of the large coastal cities in Indonesia. This form of flooding can be attributed to several processes, such as high tides due to 
astronomical tidal activity, wave action caused by winds, high sea levels combined with high river flows, and accelerated sea level rise due to climate change (Marfai et al, 2007). Water quality is also a major stress for Indonesia's population. About two thirds of public water supplies are derived from increasingly polluted surface waters (Fulazzaky, 2014). This unsafe water is one of the major sources of disease in Indonesia, and the lack of adequate sanitation facilities is a primary cause of fecal contamination in urban water supplies.

Governance plays an important role in coordinating responses to stresses and shocks, and in some cases, can act as a stressor. Prior to 1999, Indonesian governance was characterized by centralized national power and limited local and regional autonomy. But after the fall of President Suharto, government functions were devolved to local governments, who were given authority to carry out most development projects. By 2004 the process of decentralization had advanced significantly (Prasetiamartati, 2013), but local governments were not necessarily able to deliver services to their people more effectively. In fact, poorly coordinated actions between local governments led to many adverse consequences in sectors like water management.

With the aforementioned introduction of shocks and stresses, the aim of this paper is to capture lessons learned from water management approaches of Semarang and Surabaya to build city-level resilience to water related issues. This paper focus on how governance strategies has increased or decreased vulnerability to water-related issues in those cities. This evaluation are discussed in greater detail after introducing some basic theoretical grounding of vulnerability and resilience. Those theoretical ground are used to compare the methods that local governments have used to engage different stakeholders and enact various policy solutions of water related issues. This comparative analysis will create understanding about how multi-scalar elements of governance influence vulnerability and adaptive capacity at city level, specifically of high-risk low-income groups. Finally, this paper introduces a preliminary set of measures to quantify how different governance approaches could be weighted and evaluated.

\section{Theoretical Framework and Approach}

To understand the potential that adaptive governance can have in coastal cities, one must understand the concept of vulnerability. According to Neil Adger (2006), the concept of vulnerability has been a powerful analytical tool for describing susceptibility to harm, powerlessness, and marginality of both physical and social systems. In this case, vulnerability can be defined as "the propensity or predisposition to be adversely affected, and it encompasses a variety of concepts and elements including sensitivity or susceptibility to harm and lack of capacity to cope or adapt" (IPCC, 2014). Another concept is that of adaptive capacity, which is defined as "the ability of a system to adjust to climate change (including climate variability and extremes) to moderate potential damages, to take advantage of opportunities, or to cope with the consequences." (IPCC, 2007). In the two case studies that follow, the actions taken (or not taken) increased or decreased the adaptive capacity of the individuals to respond to water-related shocks and stresses. Additionally, this study applies the concept of resilience in greater detail. In keeping with the IPCC definitions, resilience refers to the capacity of social, economic, and environmental systems to cope with a hazardous trend or disturbance, responding or reorganizing in ways that maintain their essential function, identity, and structure, while also maintaining the capacity for adaptation, learning, and transformation (IPCC, 2014). Each of the concepts mentioned above are interlinked. For the purpose of this work, it can be conceptualized that in reducing vulnerability to water-related hazards, 
resilience is affected in some way or other. This paper therefore seeks to describe how the actions taken to address water related issues in the cities of Semarang and Surabaya affect the vulnerability of their people, but also their resilience to these shocks and stresses.

The "Pressure and Release" Model proposed by Blaikie et al. (2003), provides a useful starting point in this context. The model recognizes that disasters are not just natural events, but are also the product of social, political and economic environment, as these are extremely influential in structuring people's lives (Blaikie et al., 2003). Vulnerability in this model runs from root causes (such as the political economic system), to dynamic pressures (such as rapid urbanization), to unsafe conditions (unprotected structures) (Hufschmidt, 2011). These pressures and root causes, combined with natural hazards such as floods, result in disasters (Adger, 2006; Hufschmidt, 2011). In order to reduce the risk of disasters or to gain 'release', it is necessary to address these dynamic pressures and root causes. This model however, does not include a discussion of adaptive capacity and resilience. As such, we draw on the characteristics, processes, and outcomes of adaptation actions as proposed by Nelson et al. (2007). Their approach takes into consideration system flexibility and unpredictability, which need to be managed to allow desirable responses in uncertain situations (Nelson et al., 2007). This approach suggests that adaptation and adaptive capacity, as well as self-organization, are necessary for resilience. The approach also looks at multiple states, thresholds, and scales, which suits the purposes of comprehensively examining Semarang (institutionally focused, internationally assisted, community-specific) and Surabaya (peoplefocused, internally driven, at citywide scales and beyond).

Figure 1. Pressure and Release (PAR) Model

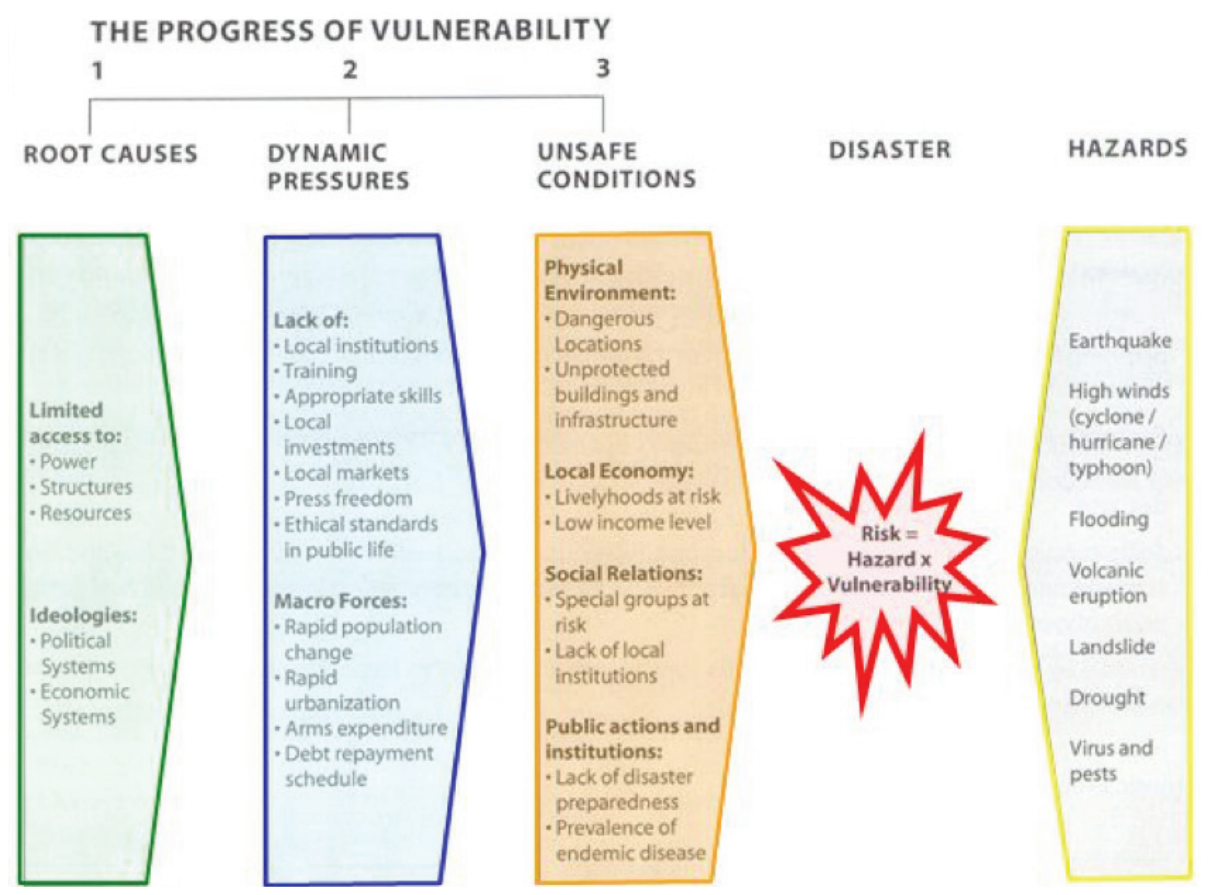

Source: Blaikie et al., 2003 


\section{Analysis: Governance Strategies on Managing Water-related Issues}

\subsection{Building Institutional Resilience in Semarang}

While Semarang's city leadership - heavily supported by international organizations - played a critical role in the adoption of "resilient" policies, their policy interventions arguably resulted in more learning among city bureaucrats than through grassroots self-organization. In 2009, Semarang was selected as one of the core participating cities in one of the Rockefeller Foundation's first major resilience programs, ACCCRN (the Asian Cities Climate Change Resilience Network). The ACCCRN program's goal, to address climate impacts in medium-sized cities in South and Southeast Asia, mainly focused on bridging technical and financial capacity gaps. Major reasons for selecting Semarang included its competent leadership and commitment to implementing and owning related projects (Sutarto and Jarvie, 2012). Over several years, the initiative launched community-specific pilot projects to restore coastal mangrove forests, increase rainwater harvesting, and develop an early flood warning system (Rockefeller Foundation, 2016). These commendable efforts certainly involved elements of community participation, but were externally financed and designed to meet predetermined city plan goals. While the Rockefeller Foundation has supported some initiatives that clearly foster self-organization, such as open-data participatory mapping of hazards (Roberts, 2015), these activities were not as common.

ACCCRN's planning outputs and technical capacity building laid the groundwork for sector-based vulnerability assessments and further government-defined, not grassroots-orchestrated actions. First, ACCCRN's 2010 "City Resilience Strategy" for Semarang provided broad recommendations, based on a vulnerability analysis of the city (Setiadi, 2010). While ACCCRN held workshops and roundtable dialogues to train bureaucrats in resilience thinking and drafting vulnerability assessments, GIZ (German foreign aid) and ICLEI (the International Council for Local Environment Initiatives) partnered with Semarang to further advise adaptation goals in the city's long term development plan (ICLEI, n.d.). By 2013, Semarang received an invitation to join another Rockefeller Foundation program for select local governments, 100 Resilient Cities. This program supported city meetings to coordinate resilient actions, eventually including a committee of dozens of top ministers and advisers, all of whom informed a more detailed and prescriptive city resilience strategy released in 2016. Three of the strategy's six thematic resilience priorities directly or indirectly address coastal flooding: sustainable water and energy, readiness for disasters and diseases, and transparent public information and governance (City of Semarang, 2016). The plan's new approach mixes prescriptive components (e.g. financial incentives for household rainwater harvesting technology) with organic components (e.g. community-based sanitation systems). However, many of its proposals - "upstream area reforestation, involving local communities" - do not necessarily empower communities to self-organize (City of Semarang, 2016). These plans are understandably meant to be ambitious long-term visions that guide future decisions. Semarang's piecemeal and often community-specific approach contrasts Surabaya's governing philosophy.

\subsection{Kampung-Centered Resilience in Surabaya}

As capital of East Java province and the second largest city in Indonesia, Surabaya has been key to Indonesia's economic development. Surabaya makes up almost half of East Java's economic growth (Damayanti, 2006). Its seaport, Tanjung Perak, acts as a hub for local, regional and international trade, known as one of the busiest ports in Southeast Asia (Ernawati, 2013). Yet while the city's significant economic opportunities attract investors and jobseekers from surrounding regions, 
leading to strong economic growth, they also lead to adverse effects associated with high urbanization. Most settlers cannot compete in the formal housing market, occupying informal settlements known as kampungs with few public services and high population densities. This is reflected by the fact that almost $70 \%$ of Surabaya population lives in only 7\% of the city's total area (Ernawati, 2013; Silas, 1989).

Physical characteristics of the city also make it vulnerable to climate change impacts. Topographically, Surabaya is located in a low-lying coastal area downstream of the Brantas River Basin, the largest river basin in East Java. Approximately $80 \%$ of the city is dominated by lowland area, ranging from 1 to $10 \mathrm{~m}$ above mean sea level (Sulma et al, 2012). These physical conditions, coupled with a significant rate of sea level rise between 5.48 and $5.80 \mathrm{~mm} /$ year (Sulma et al., 2012), make the city prone to river and coastal flooding. In fact, flooding has remained an annual phenomenon in Surabaya since the colonial era in the 18th century (Husain, 2015). Illegal shelters along riverbanks, waste-clogged drainage systems, and river sedimentation are believed to contribute to this phenomenon (Husain, 2015).

Surabaya's local government has implemented several programs to tackle water management issues, implemented mainly through a kampung-centered approach. Interestingly, through this approach, Surabaya's city government acknowledges kampungs as part of its development strategy to improve living conditions of lowincome families. Initially started in the 1920 s to prevent the spread of disease from kampungs to nearby residents, the Kampung Improvement Program (KIP) has become a national program, now implemented in hundreds of cities in Indonesia (Silas, 1992). As the strategy's original innovator, Surabaya continues to attract large numbers of study tours and cities wishing to benchmark their own progress (Bunnell et al, 2013). Through this program, Surabaya has received awards from ICLEI in 1991 and UN-Habitat in 2008 for its best practice in urban environment improvement (Bunnell et al., 2013; Husain, 2015). In addition, the approach was also replicated in Thailand and several African countries (Husain, 2015).

By providing access to basic infrastructure and economic opportunities, KIP significantly reduced the vulnerability of low-income neighborhoods to water quality issues. Basic infrastructure provided by the program include: water supply networks, access roads and footpaths along side drains, washing and toilet facilities, solid waste facilities, elementary schools, and public health centers (Silas, 1992). Almost $60 \%$ of participating kampungs are now relatively free of flood events due to this program (Husain, 2015). Meanwhile, to improve the economic capacity of low-income households, KIP promoted home-based industries such as food vending, hairdressing, and traditional mask making. The Surabaya "Green and Clean Program," the latest form of kampung-centered approaches, successfully provides economic opportunities for kampung communities through waste banks. These banks function as centers for exchanging recyclables for cash, thus reducing solid municipal waste while supporting household living expenses (Wijayanti and Suryani, 2015).

Much of the success of the kampung-centered approach can be explained by strong partnerships between various stakeholders and active involvement from both the government and the communities. From the beginning, communities eagerly took part in detecting their priorities and contributing their own resources to the program (money, labor, and building materials). On average, communities funded $50 \%$ of the program's budget (Silas, 1992). Surabaya's city government, supported by a local university, planned and implemented the program with regular consultation from community leader and elders, chosen by local people. Women, through local women organizations, also contributed significantly to the program, especially through sustainability campaigns. They monitored the use of building materials, collected money, and cleaned rubbish from footpaths and drains. The other 
significant factors contributing to the program's success were strong government leadership and cross-border cooperation. Tri Rismahrini, the city's current mayor, spearheaded the Surabaya Green and Clean campaign through a "lead-by-example" philosophy (Bunnell et al., 2013). She personally collected trash regularly and patrolled city parks at night (Weiss, 2013). Under her leadership, the city partnered with the Japanese city of Kitakyushu to replicate their best practices for waste management (Bunnell et al., 2013). The ability to reproduce Surabaya's approach, largely relying on self-organized and self-sustained community involvement, illustrates the power of governments to achieve results without external support or explicit direction.

\subsection{Comparative Analysis}

The two case studies above demonstrate how focusing at different scales (community-specific vs. citywide and beyond), using different resources (external vs. internal), and producing different outcomes (plans and trained staff vs. local participation) can build resilience in different ways. In the case of Surabaya, we see some of the dynamic pressures and root causes mentioned in the Pressure and Release Model. The KIP was able to deal with some of the underlying causes of resource and service access through infrastructure and mechanisms for economic improvement, demonstrating some validity to the model, given the rate of flood reduction. The Semarang case study, meanwhile, focused on improving the dynamic pressures of institutions and training, though it is too soon to tell whether the city's efforts will pay off.

In the Semarang case, resilience efforts were dependent on external financing and intervention, which raises path dependency questions of potentially unsustainable outside interventions. While locally empowering post-Suharto reforms intended to make cities more directly accountable and efficient in serving the needs of its citizens, most Indonesian cities have increasingly resorted to local and not regional governance solutions. The one exception has been a multi-local governing body in Java's special district of Yogyakarta. The Kartamantul Joint Secretariat, a committee constituting both low-level and high-level bureaucrats from the City of Yogyakarta and its two adjacent districts, regionally coordinates issues such as wastewater and floodwater drainage (Firman, 2010). Some notable tasks include integrating drainage and flood management plans along boundary areas of each district, as well as taking a regional watershed management approach to infrastructure planning (DELGOSEA, n.d.). While flood management and access to water resources has seen greater success under Yogyakarta's model, German foreign aid has continued to fund the initiative, which suffers from a lack of sufficiently trained staff (Firman, 2010). This demonstrates just how often external institutions have propped up attempts for resilient flood management. The KIP, on the other hand, demonstrates that resilience-building efforts can be successful without external intervention and the uniquely large sums of money Semarang received. For both of these efforts to be sustained, though, exceptional leadership and eventual partnerships with external actors were required.

Semarang not only shows the time it takes to institute comprehensive policy frameworks, but also how plans themselves do not guarantee actual actions. Committed leadership in both Semarang and Surabaya has led to continued support of ambitious actions, but a change in leadership at the top could delay funding and guidance for long-term plans at the very least. On the one hand, Semarang's City Resilience Office and Surabaya's KIP and Green and Clean Program certainly leave an influential legacy that won't be completely undone if there were to be a change. Semarang, for one, has an ambitious long-term plan that can be used to guide future leaders' actions to sustain city's resilience. It also collaborated with other cities in the 100 Resilient Cities network, placing outside pressure on the reforms made thus far. 
However, the plans mostly addressed bureaucratic technical capacity and not the lack of capacity of local people and their role in preventing floods. Whereas in Surabaya, the process to economically empower, not eliminate, informal kampungs spread quickly throughout other cities and led to locally substantial results. Perhaps decades of KIP experience allowed stakeholders to find the best way to implement a program fitting the local conditions. Surabaya's cooperation with neighboring cities and strong local support thus seemed to improve KIP's longevity and show dynamic pressures and solutions come from inside and outside city boundaries.

\section{Conclusion and Recommendation}

Comparative discussion reveals some combination of adequate financing, technical capacity, excellent leadership, an understanding of the root causes and pressures, and long-term visions is necessary for impactful governance. Several other conclusions seem evident. Resilience-building efforts need to address processes outside of city boundaries to be effective. Cities should balance efforts to govern locally with opportunities to expand financial and technical resource networks transnationally. Lastly, since not all leaders will be good, building bureaucratic technical capacity is important to help ensure successful planning and project implementation over time. Effectiveness of project implementation is equally important, though detail information on this issue in case studies is limited. However, we argue that good leadership reflected from the level of transparency and corruption are important to ensure effective project implementation. While the above two case studies seem to be at odds with each other in terms of approach, they might suggest that all aspects of good governance cannot be achieved with one initiative. There should be different attempts to address as many institutional barriers as possible, in order for resilience to truly be achieved.

With the majority of Semarang's planned goals still underway, measures of resilience are difficult to immediately quantify side-to-side with Surabaya's. However, this study proposes several metrics moving forward to better assess the resilience and impact of cities with different governance approaches. As a new emerging paradigm of development, a wealth of knowledge exists around a plethora of resilience indicators, but each of them has limitations to consider. In their analysis of 17 sets of resilience indicators, Lisa et al (2015) suggest that there is no consensus exists on how to measure resilience. Each set of indicators is influenced by its conceptual roots such as disaster management, agriculture sustainable livelihoods, and ecological. Even though indicators can only tell part of the whole story, they suggest that at least three broad criteria should be included: learning processes in order to gain better understanding of threats from previous hazard experiences and to enhance the ability to share information; Options to ensure a diversity of choices are available in coping with shocks and stresses; and flexibility emphasizes the importance of self-regulation (Lisa et al., 2015). Those three criteria are basically in conjunction with the framework used in this analysis such as the importance to address root causes and dynamic pressure of vulnerability proposed by PAR model. In term of flexibility, Nelson et. al's approach suggests the same important element of self-regulation. Measures proposed in this paper are derived from the combination of those theoretical frameworks and lessons from case studies in the two cities.

The proposed measures involves comparing existing city conditions and goals with outcomes of a particular sector, such as waste management in the context of flooding. Goals in Semarang's city resilience strategy, such as increasing local waste bank training, can thus be evaluated for impact and effectiveness using other relevant goals, such as sanctioning water polluters and increasing waste-to-energy (City of Semarang, 2016). Common metrics for inputs and/or outcomes (e.g. waste banks) also allow general conclusions to be drawn between the sector-based actions of different 
cities. The following list of criteria and indicators should act as a first step towards more comprehensive indices to measure the efficacy of resilient governance, involving both direct measures and indirect proxies. Once the relevant data collection is prioritized and operationalized, this type of framework can begin generalizing how the different governance approaches of cities like Semarang and Surabaya tangibly build resilience in different ways.

Suggested Measures for Quantifying Urban Water-related Resilient Governance:

a. Inputs

- Diversity and redundancy of resources to determine the weight of internal and external resources. Measure: percent of city funds from local, national, international sources.

- Inclusivity to determine the impacts of different kinds of capacity building Measures: access to primary and secondary education per capita, and number of locals versus government bureaucrats trained for resilience projects.

- Potential for self-organization. Measures: Percent of local awareness and access to mandatory participatory planning sessions, and number of local interest groups.

b. Outcomes

- Regional collaboration. Measures: percent of resilience projects jointly administered by actors outside city boundaries, and number of study tour exchanges reported.

- Addressing multiple root causes. Measure: cost savings from action cobenefits.

- Implementation effectiveness. Measure: city average of major corruption and transparency indices, and percent response to online city improvement complaints.

- Reaching goals of specific initiatives (waste management in the case of both Surabaya and Semarang). Measures: number of waste banks created, number of local participants, annual municipal waste reduced, waste bank money turnover. 


\section{References}

,Adger, W. N. 2006. Vulnerability. Clobal Environmental Change, 16(3), 268. Asian Development Bank. (2016). Indonesia Country Water Assessment Retrieved from https://www.adb.org/sites/default/files/institutional document/183339/ino-water-assessment.pdf.

Blaikie, P., Cannon, T., Davis, I., and Wisner, B. 1994. At Risk: Natural hazards, people's vulnerability, and disasters. London, Routledge.

Bunnell, T., Miller, M. A., Phelps, N. A., \& Taylor, J. 2013. Urban Development in a Decentralized Indonesia: Two Success Stories?* Tim Bunnell, Michelle Ann Miller, Nicholas A. Phelps and John Taylor Forthcoming in. Pacific Affairs, 86(4), 1-24.

City of Semarang. 2016. Resilient semarang strategy. Semarang, Indonesia: 100 Resilient Cities. Retrieved from: <http://www.100resilientcities.org/page//100rc/pdfs/Semarang\%20Resilience\%20Strategy\%20-\%202016_2.pdf>.

Damayanti, R. 2006. Planning Issue and Problem in Surabaya Indonesia. DIMENSI (Jurnal Teknik Arsitektur), 34(1), 40-43. Retrieved from: http://puslit2.petra ac.id/ejournal/index.php/ars/article/view/16455

DELGOSEA. "Sectoral Cooperation: Joint Secretariat Kartamantul." n.d. Retrieved from: $<$ http://www.delgosea.eu/cms/content/download/865/6148/file DELGOSEA Presentatio n-Best Practice-Kartamantul.pdf

Ernawati, R. 2013. Facing Urban Vulnerability through Kampung Development, Case Study of Kampungs in Surabaya. Humanities and Social Sciences, 1(1), 1. <http://doi.org/10.11648/j.hss.20130101.11>.

Ernawati, R., Santosa, H. R., \& Setijanti, P. 2013. Facing urban vulnerability through kampung development, case study of kampungs in Surabaya, Indonesia. development, 14, 15.

Firman, T. 2010. Multi local-government under indonesia's decentralization reform: The case of kartamantul (the greater yogyakarta). Habitat International, 34(4), 400-405. <doi:10.1016/j.habitatint.2009.11.005>.

Fulazzaky, M. A. 2014. Challenges of integrated water resources management in Indonesia. Water, 6(7), 2000-2020.

Hufschmidt, G. 2011. A comparative analysis of several vulnerability concepts. Natural Hazards, 58(2), 621-643. http://doi.org/10.1007/s11069-011-9823-7.

Husain, S. B. 2015. THE IMPROVEMENT OF KAMPONG AS AN INSTRUMENT TO MITICATE FLOODS IN SURABAYA. Jurnal Humaniora, 27(3), 317-329. http:// doi.org/10.22146/jh.v27i3.10621.

ICLEI. "International Programs." ICLEI. n.d. Retrieved from: <http://oceania.iclei.org/ local-action/programs/international-programshtml>.

IPCC. 2007. Climate Change 2007: The Physical Science Basis. Contribution of Working Group I to the Fourth Assessment Report of the Intergovernmental Panel on Climate Change [Solomon, S., D. Qin, M. Manning, Z. Chen, M.

Marquis, K.B. Averyt, M.Tignor and H.L. Miller (eds.)]. Cambridge University Press, Cambridge, United Kingdom and New York, NY, USA.

IPCC. 2014. Climate Change 2014: Synthesis Report. Contribution of Working Groups I, II and III to the Fifth Assessment Report of the Intergovernmental Panel on Climate Change [Core Writing Team, R.K. Pachauri and L.A. Meyer (eds.)]. IPCC, Geneva, Switzerland, $151 \mathrm{pp}$.

Khomarudin, M.2013. Space Based Application for Coastal Vulnerability Assessment in Indonesia. [PDF Document]. Retrieved from: <http://www.unoosa.org 
documents/pdf/psa/activities/2013/Indonesia/KhomarudinCoastalVulnerabilitylndonesia.pdf>.

Lisa, E., Schipper, F., \& Langston, L. (2015). A comparative overview of resilience measurement frameworks analysing indicators and approaches. Retrieved from www.odi.org

Marfai, M. A., King, L., Sartohadi, J., Sudrajat, S., Budiani, S. R., \& Yulianto, F. 2008. The impact of tidal flooding on a coastal community in Semarang, Indonesia. The Environmentalist, 28(3), 237-248.

Nelson, Donald R., W. Neil Adger, and Katrina Brown. 2007. Adaptation to Environmental Change: Contributions of a Resilience Framework. Annual review of Environment and Resources 32.1 (2007): 395.

Prasetiamartati, B. 2013. Policy and Participatory Local Governance in Indonesia. [PDF Document]. Retrieved from: <http://www.pk.undp.org/content $\mathrm{dam} /$ pakistan/docs/Democratic\%20Governance/Federalism International\%20Conference\%20Sept13/presentations/Day2/3rd\%2 Ms.\%2OBudiati \%20pdf.pdf>.

Roberts, Shadrock. 2015. Kathmandu and Semarang: Community Mapping and Open Data in Two Cities. Rockefeller Foundation. Retrieved from: https://www.rockefellerfoundation.org/blog/kathmandu-semarang community-mapping-and-open-data-in-two-cities/ on 29 May, 2015.

Rockefeller Foundation. 2016. The Asian Cities Climate Change Resilience Network (ACCCRN): Achievements in Building Capacities, Changing Practices, and Strengthening Networks. Retrieved from: < https://www.acccrn.net/sites default/files/publication/attach/ACCCRN-Final_small\%20size\%20for\%2 email.pdf>.

Setiadi, Rukuh. City Resilience Strategy. 2010. Semarang's Adaptation Plan in Responding to Climate Change. ACCCRN. 2010. Retrieved from: <https://www.acccrn.net/sites/default/files/publication/attach/032_6 Semarang_Resilience_Strategy_0.pdf $>$.

Silas, J. 1989. Marginal settlements in surabaya, Indonesia: problem or potential? Environment and Urbanization, 1(2), 60-70. http://doi org/10.1177/095624788900100207.

Silas, J. 1992. Government-community partnerships in kampung improvement programmes in Surabaya. Environment and Urbanization, 4(2), 33-41. http:/ doi.org/10.1177/095624789200400204.

Sulma, S., Kusratmoko, E., \& Saraswati, R. 2013. Coastal Physical Vulnerability of Surabaya and Its Surrounding Area To Sea Level Rise. MAKARA Journal of Technology Series, 16(2), 163-170. http://doi.org/10.7454/mst.v16i2.1516.

Sutarto, R., \& Jarvie, J. 2012. Integrating climate resilience strategy into city planning in Semarang, Indonesia: Climate Resilience Working Paper No. 2. Hanoi, Vietnam: Institute for Social and Environmental Transition International. Retrieved from: <http://i-s-e-t.org/resources/working-papers wpl-climate-resilience.htmls.

Weiss, S. 2013. Surabaya's Mrs. Mayor: Indonesia's Best-Kept Secret. Huffington Post. October 11, 2016. Retrieved from: <http://www.huffingtonpost.com stanley-weiss/surabayas-mrs-mayor-indon_b_3785172.html>.

Wijaya, N. 2015. Climate Change Adaption Measures in the Coastal City of Semarang, Indonesia: Current Practices and Performance. Jurnal Perencanaan Wilayah Dan Kota, 26(1), 28-42. doi:10.5614/jpwk.2015.26.1.4

Wijayanti, D. R., \& Suryani, S. 2015. Waste Bank as Community-based Environmental 
Governance: A Lesson Learned from Surabaya. Procedia - Social and Behavioral Sciences, 184(August 2014), 171-179. http://doi.org/10.1016/j sbspro.2015.05.077.

Wingqvist, G.O. and Dahlberg, E. 2008. Indonesia Environmental and Climate Change Policy Brief. University of Gothenberg. Retrieved from: <http://www sida.se/globalassets/global/countries-and-regions/asia-incl.-middleeast/indonesia/environmental-policy-brief-indonesia.pdf>. 